\title{
Venezuelan migrants in Spain
}

\section{Sandra Issel-Dombert}

Venezuela is experiencing an unprecedented exodus as a result of ongoing political, economic and humanitarian crises. While the majority of emigrants remain in neighbouring Latin American countries, the US and Europe are also among the preferred destinations. The way migrants are covered in the media shapes public opinion and has an impact on their integration into society. Therefore, the aim of this paper is to examine the coverage of Venezuelan migrants in the Spanish press in a timeframe from 2015 to 2020. For this purpose, a linguistic discourse analysis is conducted. The results contrast with the current state of research. With the help of the sociological othering-theory and the concept of the so-called aporofobia, it is possible to explain how the image of good (and bad) migrants is discursively constructed.

Keywords: digital discourse analysis, collocations, Spain, Venezuela, triangulation of quantitative and qualitative methods

Migrantes venezolanos y venezolanas en España. Venezuela está experimentando una emigración sin precedentes como resultado de las actuales crisis políticas, económicas y humanitarias. Aunque la mayoría de los emigrantes permanezca en los países vecinos de América Latina, los Estados Unidos y Europa también se encuentran entre los destinos. La forma en que los migrantes son reportados en los medios de comunicación influye en su integración en la sociedad. Por lo tanto, el objetivo de este artículo es examinar como la prensa española informó sobre los migrantes venezolanos en el período comprendido entre 2015 y 2020. Para ello, se realiza un análisis del discurso lingüístico. Los resultados contrastan con el estado de la investigación hasta la fecha. Con la ayuda de la teoría del othering de las ciencias sociales y el concepto de aporofobia, se puede explicar cómo se construye discursivamente la imagen de los buenos (y de los malos) migrantes.

Palabras clave: análisis del discurso en contextos digitales, colocaciones, España, Venezuela, triangulación de métodos cuantitativos y cualitativos.

\section{Introduction}

This paper analyses the Venezuelan migration crisis - the fastest mass displacement unrelated to a war or a natural disaster in contemporary South America. Against a backdrop of ongoing hyperinflation, political 
unrest, violence, and a humanitarian crisis with a lack of food and medicine, UNHCR ${ }^{1}$ estimated that, out of an original population of 32 million, 5.5 million Venezuelans have left their country since 2015. This has resulted in a dramatic shift with Venezuela being transformed from an immigrant country to the scene of the largest recorded migration crisis of Latin America.

This trend was not even reversed by the corona crisis. Around 50,000 Venezuelans returned to their home country ${ }^{2}$ - a negligible proportion in comparison to the total number of Venezuelan migrants. The majority of Venezuelan migrants remained in South America. According to the International Organization for Migration (IOM), the neighbouring country of Colombia has become the largest host country at 1.8 million migrants. Peru hosts 861,000 migrants, Chile 455,500, Ecuador 366,600 and Brazil 353,500. Only a minority was able to migrate to the United States or Europe. Spain in particular stands out as the largest destination country in Europe with currently 323,575 Venezuelan migrants (see IOM 2020). Spain and Venezuela are intertwined by an extended colonial and migration history. Venezuela was one of the most popular emigration destinations for Spaniards from the $19^{\text {th }}$ to the mid $20^{\text {th }}$ centuries. This may also partly explain the direction current Venezuelan migration is taking.

Not only the perspective of the migrant group is relevant in the migration process. The aim of this paper is to explore how the media in the host community Spain perceive Venezuelan migrants. Attitudes to migrants in the host community matter. Social psychological research demonstrates that perception and attitudes of members of the host country towards migrant groups have an impact on their integration process (see Froehlich/Schulte 2019). "Integration can only be achieved successfully if the dominant group has an open and inclusive attitude towards cultural contact and the maintenance of different identities. (...) integration depend on the stance of the majority group" (Sancho Pascual 2019: 2). From the perspective of communication studies, it was shown that there is a higher probability of violence being exercised against "others" who are portrayed in the media as perpetrators or victims of violence (see Scheufele/Brosius 2001: 448, 468). From a linguistic point of view, Garrido/Codó (2017: 32) provide an example of the ways in which migrants are predominantly represented as unqualified workers in Spanish public discourse. This devalues their qualifications and thus makes their integration into the labour market more difficult.

Therefore, sound knowledge of prevailing attitudes in the host community is relevant for the integration of migrants. With this in mind, the paper addresses the following questions: 1 . Which discursive constructed attitudes about Venezuelan migrants and migration are prevalent in 
the host community Spain's press? 2. (How) Does the coverage of the Venezuelan migrants in Spain differ in the broadsheets El País and El Mundo? A discourse linguistic approach to migration linguistics is implemented to explore discursively constructed attitudes in a host community. This reveals linguistic patterns - and the attitudes behind them - used in a host community to talk about migration or a specific migrant group.

In the next section, the home community Venezuela and the country of destination Spain are presented. Section 3 discusses previous studies in the field of the representation of migrants and refugees in Spain. In section 4 , the research design will be developed, section 5 goes on to discuss the results of the qualitative and quantitative analysis and in the final section, conclusions are drawn.

\section{The context: Venezuela and Spain}

\subsection{The home community Venezuela}

A starting point for a discourse analysis is the description of the contextual information, in this case the development of emigration and immigration of the home country Venezuela (2.1) and the host community Spain (2.2).

Spain and Venezuela share a long colonial and migration history dating back to 1498, when Columbus reached the Venezuelan coast. The South American State at the Caribbean Sea gained independence in 1811. Venezuela's immigration history can be divided into two decisive phases. The first lasted until the 1960s and is characterised by immigration from Europe. The second phase began in the 1970s and is characterised by Latin American migrants. According to Páez/Phélan (2019: 323), 20,000 of the 26,000 immigrants came from Spain already between 1824 and 1936. Further Spaniards emigrated to Venezuela after the end of the Spanish Civil War and the Second World War. Between 1945 and 1958, $78 \%$ of registered migrants originated from Southern Europe, North America, and Colombia. About a third of the Spanish immigrants came from the Canary Islands and another third from Galicia. Between 1958 and 1970, $15 \%$ of the Venezuelan population had an immigrant background; the majority had migrated from Spain, Portugal, and Italy, as well as from Lebanon and Syria (see Páez/Phélan 2019: 323).

Socio-economic and political crises within Latin America changed Venezuela's immigration profile in the 1970s. Considered the world's most oil-rich country, Venezuela achieved stability through the success of oil on 
world markets. This made Venezuela a popular receiving country for Latin American migrants, with migration particularly from Colombia, Argentina, Chile, Uruguay, and Bolivia (see Vargas Ribas 2018: 99).

In terms of immigration, a downward trend became apparent from the 1980s onwards due to a slump of the economic system. 23.02.1983 can be identified as the turning point, known as viernes negro 'Black Friday', which heralded the end of an era of prosperty intended through oil-funds. The government of Luis Herrera Campins (1979-1984) took a series of economic reforms, including the devaluation of the bolivar, the national currency (see Vargas Ribas 2018: 100, 120). Such a mechanism is generally used to stimulate the domestic demand and to achieve a positive trade balance surplus (i.e. more exports than imports). As Venezuela had focused on oil production to the detriment of other sectors of the economy, a fall in the price of oil on the world market led to a sharp drop in the price of the main export product, oil. At the same time, the prices of other products had risen sharply as a result of inflation. The country plunged into a deep recession. Due to an increase in prices, popular uprisings - the so-called el Caracazo - emerged and were bloodily suppressed (see Páez/Phélan 2019: 324). During the '80s and ' 90 s, the country recorded one of its worst economic periods (see Freitez 2011: 14). The Venezuelan emigration balance turned into negative. And although there was an economic upturn between 2003 and 2008 , thanks to the rise in oil prices, this failed to lead to a continuation of Venezuela's past as an immigration country (see Freitez 2011: 18). With Freier/Castillo Jara (2020), the recent large-scale migration to Spain can be subdivided into three phases. The first phase took place at the turn of the millennium with the re-election of Hugo Chávez. The main motives for migration were mass expropriation, the nationalisation of industries, growing insecurity, social and political tensions. The middle class in particular migrated. Main destinations were the United States and Europe. The second phase dates back to 2012 with the end of the boom in Latin American exports and the re-election of Hugo Chávez for a third term. This time, the profile of emigrants shifted towards less privileged parts of the population. Countries that are geographically closer - such as Colombia, Panama, and the Dominican Republic - have become the main host countries. The third phase started around 2015, when Nicolás Maduro had been elected successor of Chávez, who had died in 2013. Migration from Venezuela globally increased by $110 \%$ between 2015 and 2017, rising from 700,000 to 1.5 million migrants (see UN 2018: 1). Encovi, a survey on living conditions, documented that Venezuelans lost an average of 11 kilograms in 2017. According to Encovi (2019-20), even before the eruption of Covid-19, $96 \%$ of households were found to be in poverty and $79 \%$ 
in extreme poverty. The latter meaning that the income received is insufficient to cover the expenses of food supply. The demographic profile of the emigrants in this phase is heterogenous, also including lower classes and with them an increasing vulnerability (see Freier/Castillo Jara 2020).

\subsection{The country of destination Spain and its immigra- tion profile}

Over the last 20 years, Spain has become the destination of millions of immigrants, which has led to a profound social transformation of Spain from an emigrant country to one of the most important immigration countries in the EU today (see Issel-Dombert 2019). Spain is among the ten countries with the highest proportion of migrants worldwide (see Froehlich/Schulte 2019).

The Spanish state's experience of mass migration is thus still relatively recent. At the same time, the immigrants are characterised by a pronounced ethnic, cultural and linguistic heterogeneity, since according to the data of the Padrón Continuo of the Instituto Nacional Estadistico (INE), people from at least 122 nations currently live in Spain. Dealing with this new migration-related multilingualism, multiculturalism, superdiversity and integration of migrants creates central challenges for Spanish society and politics. The decisive, rapid increase in immigration to Spain occurred in the years around the turn of the millennium (see Figure 1) - a time when the Spanish economy was booming, thus opening up new job opportunities for foreign workers:

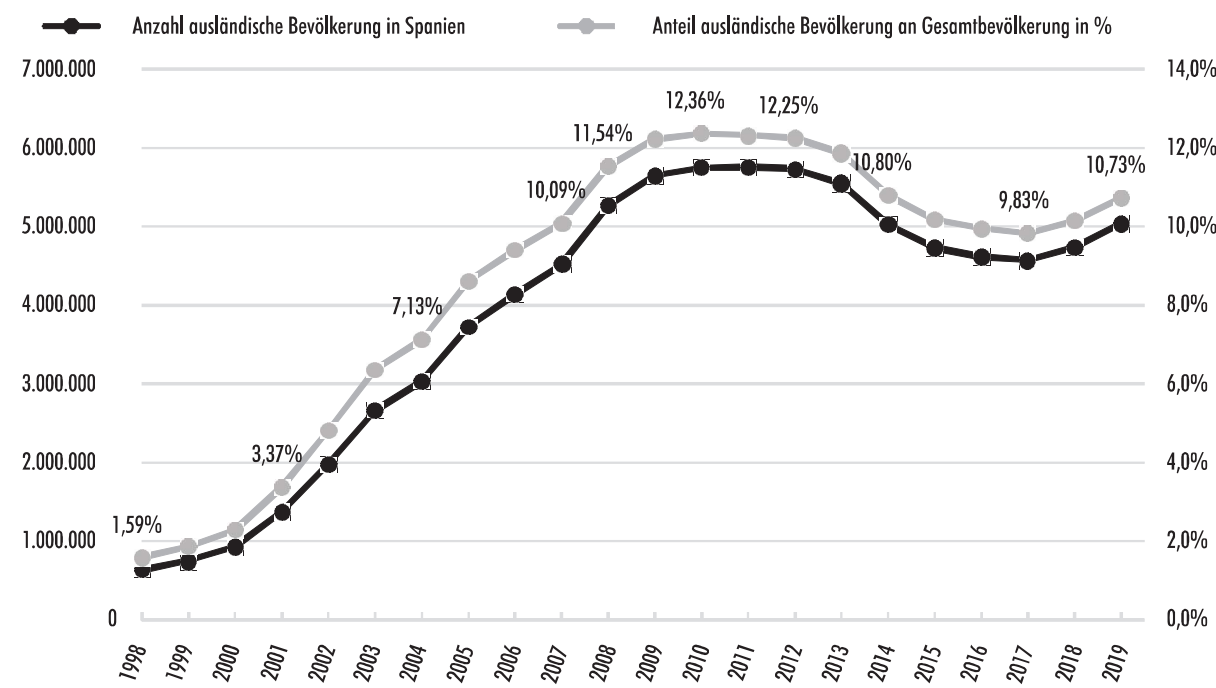

Figure 1: Foreign population in Spain 1998-2019.

Source: Padrón Continuo (INE), own representation 
The black line in Figure 1 indicates the evolution of the foreign population in Spain from 1998 to 2019, whereas the grey line represents the evolution of the foreign population as a percentage of the total population. In 1998 there were 637,085 foreigners living in Spain, representing $1.59 \%$ of the total population. Just three years later, the number of foreigners had doubled to over 1.3 million. Ten years later, in 2008 , the proportion of the foreign population of $5,268,762$ immigrants in relation to the total population had increased more than tenfold to $11.54 \%$. Two years later a peak value of $12.36 \%$ was reached. According to the latest surveys for the year 2019, the current share of the foreign population is $10.73 \%$. However, the latter data should not only be interpreted as a decrease in the share of foreign population due to returnees to their home country. Rather, it must be taken into account that between 2006 and 2018 more than 1.2 million people received Spanish citizenship and thus no longer fall into the statistics of the foreign population (see Evolución de las concesiones de nacionalidad española por residencia según sexo y provincia del Registro Civil).

Especially in the last 5 years, an increase in the immigration of Venezuelans to Spain can be observed. Whilst during the 1990s the number of Venezuelans was relatively low, this changed at the turn of the millennium. In 2008, already 40,000 Venezuelan immigrants lived in Spain (see Freitez 2011: 23). Within the past five years their number has almost doubled to 323,575 (see Figure 2):

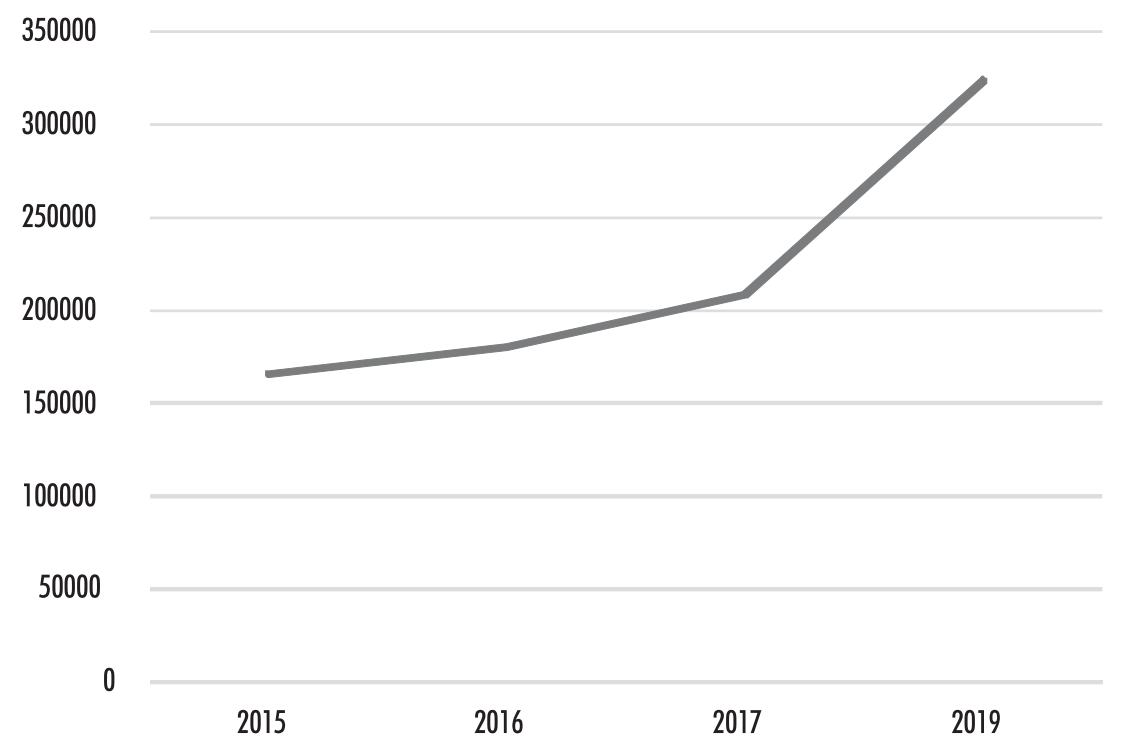

Figure 2: Number of Venezuelan citizens in Spain in the period from 2015 to 2019. Source: IOM, own representation

Between 2017 and 2018, Spain ranked fourth - after Colombia, Peru, and the United States - as a destination for Venezuelans, receiv- 
ing $9 \%$ of the estimated total of Venezuelan migrants (see Páez/Phélan 2019: 326).

Venezuelan migrants also topped the list of asylum requests in Spain. They submitted more than twice as many asylum applications in 2019 as in the previous year with more than 45,000 applications according to the data of the European Asylum Support Office (EASO 2020). On average, this corresponds to 123 asylum applications per day. About nine out of ten applications in the EU were made in Spain between January 2019 and March 2020 (see EASO 2020). More women than men migrate to Spain, with the largest age group ranging from 20 to 35 (see INE).

\section{State of the art: The discursive construction of migrants in Spain}

Research on the attitudes of migrants in Spain begins with Spain's transformation from a country of emigration to a country of immigration (see section 2.2). Opinion polls concerning immigration find a more open attitude of Spaniards towards immigration compared to the results of other European countries. According to the survey of the sociological research centre CIS (CIS 2020), immigration was ranked eleventh among the concerns of Spaniards in September 2020. In other words, it seemed to be of less importance than issues such as unemployment, problems of economic nature, healthcare, corruption, and fraud.

Recently, there has been growing interest in the field of representations of several migrant groups in Spain. A major finding in prior research is a broad spectrum of pejorative discursive constructions of migrants in Spanish media and press. $^{3}$ Igartua Perosanz/Otero Parra/Muñiz (2007) compare the news coverage of the channels TVE1, Antena 3 and Tele 5 with daily newspapers (El Pais, El Mundo, ABC, La Razón) in 2004 . They demonstrate that $70,6 \%$ of the news items analysed report negative events from the perspective of immigrants, while only $19,1 \%$ approach the immigration process from more positive perspectives (see Igartua Perosanz/Otero Parra/Muñiz 2007: 162, 167). The authors point out that the Madrid train bombings, the so called $11-M$, could cause an upset of negative reporting on immigration. Nevertheless, the press continues to be the medium that offers the most positive view of immigration compared to television. The latter providing a more sensationalist coverage of immigration (see Igartua Perosanz/Otero Parra/Muñiz 2007: 167-168). Moreover, the authors document that a frame predominates which links immigration with violence and/or delinquency, followed by the traditional framing of the

Lengua y migración / Language and Migration 13:2 (2021), 7-28 Edición impresa: ISSN 1889-5425. Edición en línea: ISSN 2660-7166. C Universidad de Alcalá 
illegal entry of immigrants by boat. On positive framing, the authors observe an increase in the framing of the economic contribution by immigrants (see Igartua Perosanz/Otero Parra/Muñiz 2007: 168). Another finding is that the origin of migrants matters. Immigrants from Europe and South America experience a more favourable reporting than immigrants from Asia or Africa (see Igartua Perosanz/Otero Parra/Muñiz 2007: 169-170; see Sancho Pascual 2019: 5).

A further key feature of reporting on immigrants in Spain is the dichotomy between "them" and "us". Considering Latin American migrants, Zapata-Barrero/Van Dijk (2007: 11) find that this polarisation is expressed in Spanish public discourse through stereotypes. An example are stories about immigrants arriving on boats, although the vast majority of immigrants arrive by plane or via routes from Eastern Europe. Another discursive strategy is the use of vagueness. While "bad" things "they" do are described in detail, "bad" things "we" do are only vaguely described (see Zapata-Barrero/Van Dijk 2007: 11). Furthermore, the authors observe (neo)colonialist discourses, i.e. the discursive construction of peninsular "superiority" in contrast to the discrimination of Latin Americans in all fields of Spanish society (Zapata-Barrero/Van Dijk 2007: 11). Based on a quantitative approach, Salas Guerra (2011: 45) emphasises the discursive construction of a link between crime and immigration, analysing articles of one liberal quality newspaper (El Pais), one conservative quality newspaper $(A B C)$, two free daily newspapers ( $A D N$ and 20 Minutes) and two newspapers from the Latino American diaspora (Si, se puede and Latino) in the period from October to November 2008. Böhm (2015: 256) also summarises as result of a frame analysis that immigration in Spanish press discourse is combined with racism, delinquency, problems, and crises.

Research also pointed out that migrants are rarely described as individuals, instead they are constructed as a homogenous mass. Exploring photos in the coverage in a sample of the Spanish daily newspapers $E l$ País, El Mundo, La Razón and ABC from June 2013 to June 2014, Franquet Santos Silva/Real Rodríguez/Beriain (2015) illustrate this. When immigrants appear in photos, the percentage of group photographs increases (see Franquet Santos Silva/Real Rodríguez/Beriain 2015: 300). The aspect of a depersonalised representation of migrants can also be seen in the use of metaphors. Plötner (2018) draws the attention on the socalled "refugee crisis" 2015-16 and examined the representation of refugees in the Spanish daily newspapers El País and La Razón in February 2016. Both newspapers dominantly use metaphors from the field of water (see Plötner 2018: 156) and thus constructing a homogenous representation. In a similar way, Gruber (2018: 70-79) also shows that the concept migration is a moving mass of water dominates the Spanish press 
discourse during the refugee crisis of 2015/16, followed by the concept migration is a natural disaster and migration is war. The dehumanising potential is generated through the image of an unwanted, out-of-control force of nature (see Baker/Gabrielatos/Khosravnik/McEnery/Wodak 2008: 287). Metaphors have an outstanding function in discourses on immigration. They are used with their argumentative function, which is fed by their broad pragmatic and semantic functional spectrum. Thus, they are used to conceptualise and designate the abstract or the new, and to create plausibility via their inherent pictoriality (see IsselDombert/Wieders-Lohéac 2018: 81).

A tentative conclusion on this point is that so far little effort has been devoted to the representation of Venezuelan migrants in Spain's public discourse. It also remains open whether there are differences between newspapers in their reporting on migrants. These desiderata lead to the following hypotheses:

1. The first hypothesis is that differences in the reporting between El País and El Mundo are expected, as both newspapers represent different political spectrums.

2. Due to prior research on Latin American migrants and various strategies of a negative representation, the second hypothesis assumes a discursively constructed negative representation of Venezuelan migrants in Spanish press.

\section{Research design: Criteria for the data collection and data processing}

In order to grasp the public discourse of a society on a specific topic, it has been proven useful to consider press releases due to their range and digital availability. Spanish media and press are characterised by a number of specific features which have consequences for the corpus compilation. Firstly, there is a long tradition of the so-called prensa de corazón 'rainbow press', but they exclude immigration from their reporting. Secondly, mass newspapers in the style of English or German tabloids could not establish themselves in Spain. Thirdly, weekly news magazines like Le Nouvel Observateur are also not established in Spain. In view of these characteristics, relevant quality newspapers are used to build a corpus and selected according to the criteria of high reach as well as a range of political views to ensure that opinion-forming organs and their contents are taken into account. The corpus includes the key media El País and El Mundo. Both dailies emerged after Franco's death 
and are based in Madrid. They provide a reference point in the Spanishspeaking world. Founded in 1976, El Pais is the largest Spanish national daily newspaper and the world's most consulted digital newspaper in Spanish language. ${ }^{4}$ Its orientation is considered left-wing liberal and close to the socialist party PSOE (see von Tschilschke 2013: 635). The second largest Spanish daily newspaper El Mundo was created 1989 as a counterbalance to El Pais, oriented more towards the conservative spectrum. It is considered as centre-right, close to the People's Party (see von Tschilschke 2013: 635-636).

Data was collected with the database LexisNexis. In order to reduce the researcher bias and to increase objectivity in the selection of the query, a pretest was carried out in which different strings were tested. This showed that the string asilo is less relevant for the press discourse on Venezuelan migrants in Spain. The search strings used for the corpus compilation were inmigra! OR migra! AND venez! AND españ! OR madrid. The exclamation mark is used in LexisNexis to find the root form of the lexeme as well as all its other variants. This means that with the query " migr!" the following lemmas will be considered: migración, migrante, migrantes, migratorio, migrar (and all its conjugated forms). To avoid false positives such as migrador/migradora 'migratory bird' or migraña 'migraine' and to capture the Venezuelan coverage on flight and migration, "venez!" has been added as obligatory search query. In order to capture the public discourse on Venezuelan migrants in Spain - and not the discourse on Venezuelan migrants in Latin America in general - the string “españ!” was made mandatory as a further search term. Madrid was chosen as an optional search term as there lives the largest Venezuelan diaspora in Europe. As this paper focused primarily on the situation of Venezuelan migrants in Spain and not on the political and social situation of their home country, the news coverage of the latter was disregarded and therefore not taken into account during the formation and evaluation stages of the corpus.

Regarding the time factor, the starting point for the corpus compilation is a key moment, as the increase in Venezuelan migration in Spain was about to skyrocket in 2015 (see section 2.2). Another argument is that in 2015 , for the first time since the financial crisis, more migrants had arrived than left. For these reasons, the period from January 1, 2015 to September 15, 2020 was chosen as time span for the corpus. The consideration of 5 years and about 9 months allows not only a synchronous approach, but also to trace changes in the discourse within the selected period.

Based on the abovementioned criteria and decisions, the corpus comprises 672 articles, containing 750,918 tokens. In terms of data processing, meta-data was removed, and the corpus data was tagged with the Spanish Freeling part-of-speech-tagger to prepare the data for the analysis. 


\section{Results}

\subsection{Quantitative results}

From a quantitative point of view, the findings can be summarised as follows: Firstly, El Pais devoted with 444 articles almost twice as many contributions to the topic of Venezuelan migration as El Mundo did with 228 articles during the period under review. When comparing the tokens, El Pais is 1,54 times bigger with 455,556 tokens than the El Mundo corpus with 295,362 tokens. Previous studies confirmed that the amount of reporting of migration in El Pais is higher than in newspapers of the conservative spectrum. Plötner (2018: 154) mentions that during the period under review in her study, $29 \%$ more articles were published in El País than in La Razón.

Secondly, the distribution of the articles, arranged according to their year of publication, creates a longitudinal view of media attention. Table 1 shows an overall increase in reporting on the topic of Venezuelan migration in El País and El Mundo in the period under review:

\begin{tabular}{|c|c|c|}
\hline & Articles in El País & Articles in El Mundo \\
\hline $\mathbf{2 0 1 5}$ & 34 & 19 \\
\hline $\mathbf{2 0 1 6}$ & 51 & 23 \\
\hline $\mathbf{2 0 1 7}$ & 69 & 25 \\
\hline $\mathbf{2 0 1 8}$ & 91 & 60 \\
\hline 2019 & 113 & 64 \\
\hline $\mathbf{2 0 2 0}$ & 86 & 37 \\
\hline total & 444 & 228 \\
\hline
\end{tabular}

Table 1: Number of articles on Venezuelan migration in El País and El Mundo (2015-2020)

As argued in section 2.1, the continuous increase in coverage can on the one hand be explained by the fact that more and more Venezuelans have left their homeland. On the other hand, as pointed out in section 2.2, the Venezuelan diaspora in Spain has become increasingly larger. This leads to the hypothesis that the issue has also become more present in Spanish public discourse.

\subsection{An inductive, corpus-driven starting point: Collocations}

A starting point for a systematic, corpus-driven identification of typical language patterns in corpora is a collocation analysis. The core idea of a 
collocation is that "certain words have a tendency to occur near each other in natural language" (Evert 2008: 1212). The concept of collocation adopted here follows the tradition of British contextualism. "A collocation is a sequence or combination of words that occur together more often than would be expected by chance". ${ }^{5}$ Collocation analyses can be statistically calculated using corpus-linguistic methods. This offers the advantage that larger corpora can be examined systematically and entirely, so that the quality criterion of objectivity in the analysis is given. Currently, over fifty different statistical measures are available (see Evert 2008: 1243). In this study, the collocation analysis was carried out with the feature Word Sketch ${ }^{6}$ in the software Sketch Engine. To calculate the strength of collocations, Sketch Engine uses the statistical measure logDice score, which is "well-suited for rigid combinations such as fixed multiword units" (Evert 2008: 1235). "It is only based on the frequency of the node and the collocate and the frequency of the whole collocation (co-occurrence of the node and collocate). LogDice is not affected by the size of the corpus and, therefore, can be used to compare scores between different corpora." The collocation analysis was carried out for the adjective venezolano, - a. After extracting collocates with Word Sketch, they were classified according to the features they apply to venezolano,-a using the concordance function (see Baker/Gabrielatos/Khosravnik/McEnery/Wodak 2008: 286).

The most common collocates for the node - the search word venezolano,-a - are nouns. 42 collocates occur in combination with venezolano,-a in El Pais and 40 in El Mundo. First and foremost, one can observe a high degree of common collocates between El Pais and El Mundo. 18 collocates overlap in both corpora. ${ }^{8}$ Examples for these overlappings are oposición 'opposition', opositor 'opponent', gobierno 'government', régimen 'régime', presidente 'president', demócrata 'democrat', chavismo 'Chavism' relating to the thematic level of the discourse, the policy domain. Other collocates in both corpora are linked to migration: éxodo 'exodus', diáspora 'diaspora', inmigrante 'in-migrant', ciudadano 'citizen'. It is noticeable here that El País, unlike El Mundo, also uses significantly refugiado 'refugee' in combination with venezolano, while $E l$ Mundo uses significantly exiliado 'expat'. Following the dictionary of the Real Academia Española ( $R A E$ ), exiliado stresses political motives ${ }^{9}$, while refugiado focuses on the discussion whether Venezuelans should be granted refugee status. The data also indicates discourse actors, because both corpora have a high frequency of proper nouns (El Pais: petkoff, teodoro, leopoldo, lópez, josé, nicolás, dudamel, gregory, gustavo, márquez, briceño, lisbeth, diaz; El Mundo: saleh, lorent, antonio, lópez).

With regard to differences, it can be seen that a number of professions occur in El Pais (artista, ingeniero, estudiante, abogado, peri- 
odista), while in El Mundo only poeta occurs with venezolano, -a. El País also combines areperas with venezolano, -a., i.e., restaurants of a Venezuelan culinary specialty. In El Mundo tragedia 'tragedy', víctima 'victim' and multimilionario 'multimillionaire' occur.

\subsection{A qualitative approach: The representation of Venezuelan migrants in Spanish press}

This chapter examines the results of the collocation analysis in qualitative terms. As we will see, the qualitative analysis reveals that the press coverage of Venezuelan migrants mainly focuses on their social and professional integration in Spain. Although the vulnerability of Venezuelan migrants doesn't go unmentioned in the reporting, it is more often addressed in the context of the political situation in Venezuela, which is beyond the scope of this paper to keep the discussion manageable.

In El Pais and El Mundo, proper nouns occur with venezolano,-a in narrative contexts of success stories about “average" Venezuelan migrants and the migrated Venezuelan elite. Example (1) presents a success story related to "average" Venezuelan migrants:

(1) En 2008 había tan pocos venezolanos en Madrid que dos pequeños fabricantes de queso al estilo de ese país, José Luis Marín y Fernando Rodríguez, tenían que buscar a sus compatriotas por la ciudad, montados en su Opel Astra. Hoy estos dos queseros venden sus productos autóctonos en Carrefour o El Corte Inglés. Su empresa Antojos Araguaney, emplea a 120 personas y tiene planes de expansión ambiciosos. [...] El éxito de Antojos Araguaney se debe al trabajo duro y a un aumento extraordinario de sus consumidores potenciales. [...] Ahora, Antojos Araguaney es motivo de orgullo para los venezolanos en Madrid y un ejemplo para emprendedores que buscan prosperar en España. "Yo siempre les doy el mismo consejo: trabajo, trabajo y trabajo", dice Marín, que a sus 69 años no tiene planes de tomar un descanso. (El País, 10.01.2019).

[In 2008 there were so few Venezuelans in Madrid that two small Venezuelan-style cheese makers, José Luis Marín and Fernando Rodríguez, had to look for their compatriots in the city, driving in their Opel Astra. Today these two cheese makers sell their local products at Carrefour or $E l$ Corte Inglés. Their company, Antojos Araguaney, employs 120 people and has ambitious expansion plans. [...] Antojos Araguaney's success is due to hard work and an extraordinary increase in potential consumers. [...] Now, Antojos Araguaney is a source of pride for Venezuelans in Madrid and an example for entrepreneurs seeking to prosper in Spain. "I always give them the same advice: work, work, work," says Marín, who at 69 has no plans to take a break. (My translation, S. I.-D.)] 
Example (1) focuses on two protagonists who had built a successful business, from scratch to a global player co-operating with Europe's largest department store chains, selling products of their home community. On the one hand, the two Venezuelans migrants are attributed values such as being ambitious and hard working. By emphasising one's own efforts and the success based on them, the narrative of the American Dream is created - from rags to riches, advancement through deprivation and hard work. By giving immigrants a voice and thus, by creating visibility, narratives are crucially important (cf. De Fina 2018). On the other hand, this storytelling highlights the added economic value that is achieved with the help of migrants ("employs 120 people", "an example for entrepreneurs seeking to prosper in Spain"). Reporting on the benefits that migrants bring to the recipient society is an unexpected finding in contrast to prior research. Giró/Jarque (2006: 267) pointed out, that the voice of migrants in Spanish press is often thoroughly excluded when the debate on immigration dealing with political and economic aspects. They also show that the voice of migrants does not appear in reporting on crime and prostitution, apart from victimising statements.

The following example highlights the argumentation that Venezuelan migrants are not only an economic enrichment for Spain, but contribute to cultural enrichment:

(2) La huella cultural en Madrid se siente en rincones como el mercado de Maravillas, en las nuevas areperas por la ciudad que sirven el producto más popular, la arepa, o en el auge que experimenta la liga de sóftbol, una variante del béisbol, el deporte rey del país sudamericano. Son una adición a una región cada vez más diversa. (El País, 10.01.2019)

[Madrid's cultural footprint can be felt in such places as the Maravillas market, in the new areperas around the city that serve the most popular product, the arepa, or in the rise of the softball league, a variant of baseball, the king of the South American country. They are an addition to an increasingly diverse region. (My translation, S. I.-D.)]

This result is also a rare finding in media coverage of migrants in that El País focuses on characteristics of the Venezuelan diaspora that are considered as a part of Venezuelan identity. The added economic and cultural value of Venezuelan migrants is also highlighted by direct quotes from Spaniards:

(3) Según los comerciantes, los españoles están adaptando muy bien su paladar al gusto venezolano. "A los españoles les encanta probar sabores diferentes y si están hechos con amor mejor todavía”, dice la gerente de Sabores Tienda 
Gourmet. "La vanguardia culinaria de España está en sus mercados", dice un cliente madrileño, Javier Criado, de 53 años, que agradece que además de productos latinos en Maravillas también puede encontrar ingredientes asiáticos que no encuentra en otros lugares de Madrid. (El País, 27.01.2019)

[According to the merchants, the Spanish are adapting their palate very well to the Venezuelan taste. "Spaniards love to try different flavours and if they are made with love, even better," says the manager of Sabores Tienda Gourmet. "The culinary vanguard of Spain is in its markets," says a Madrid customer, Javier Criado, 53, who is grateful that in addition to Latin products at Maravillas he can also find Asian ingredients that he cannot find elsewhere in Madrid. (My translation, S. I.-D.)]

Direct quotes from members of the host community have a reinforcing function in the positive representation of Venezuelan migrants. Furthermore, (3) also gives deep insights into trends in reporting. The finding does not conform with Franquet Santos Silva/Real Rodríguez/Beriain (2015: 300). Their data indicates that interactions between migrants and members of the local community in photos do not exceed $6.4 \%$.

It is also remarkable that not only "average" migrants are addressed, but also the Venezuelan elite, as illustrates example (4):

(4) López Gil es ahora el primer venezolano en el Parlamento Europeo. (El Mundo, 17.01.2020)

[López Gil is now the first Venezuelan who has a seat in the European Parliament. (My translation, S. I.-D.)]

The presence of the Venezuelan elite in Spanish press is a surprising finding, as it contrasts with previous research on the coverage of migrants in the Spanish media. Zapatero/van Dijk (2007: 11) state that in quotations, the "us vs. them" dichotomies are often come into play by citing "our" elites (e.g. authorities, politicians and scientists), while "their" elites are mentioned much less frequently. A further example along these lines is given by El Pais:

(5) en una callecita del muy madrileño barrio de Chueca [...] se reúnen por las tardes los intelectuales venezolanos para escuchar a escritores y charlar tomando vino. El dueño es Guillermo Barrios, de 67 años, el antiguo decano de arquitectura de la universidad más grande de Venezuela, la Central. [...] (El País, 25.01.2019)

[in a small street in the very Madrid neighbourhood of Chueca [...] Venezuelan intellectuals meet in the evenings to listen to writers and chat 
over wine. The owner is Guillermo Barrios, 67, the former dean of architecture at Venezuela's largest university, the Central. (My translation, S. I.-D.)]

In (5), Venezuelans are presented as well educated. This representation is extended to "average" Venezuelan migrants:

(6) Geraldine Pérez, de 25 años, llegó hace un mes a Madrid procedente de Caracas (Venezuela). Esta licenciada en Periodismo. (...) Geraldine es una de los miles de venezolanos que han fijado su residencia en España durante los últimos años huyendo de un régimen (El Mundo, 18.03.2018)

[Geraldine Pérez, 25, arrived in Madrid from Caracas, Venezuela, a month ago. She has a degree in journalism. (...) Geraldine is one of the thousands of Venezuelans who have taken up residence in Spain in recent years, fleeing a regime (My translation, S. I.-D.)]

In (6), the individual fate of a Venezuelan woman is told. Already in the second sentence it is revealed that she has a university degree. She is then linked to the total number of Venezuelan migrants in Spain via a pars-pro-toto relation. This way, the positive representation is also transferred, more or less implicitly.

The collocation analysis revealed another facet of the portrayal of Venezuelan migrants in the Spanish press with a socio-economic nature: In El Mundo, venezolano-, a co-occurred with multimillionario. A qualitative examination of the contexts shows that it refers to the acquisition of real estate by Venezuelan migrants:

(7) En 2018 los ciudadanos venezolanos compraron un total de 278 casas en este país, un $20 \%$ más que un año antes y más del doble de las transacciones realizadas en 2014. Es decir, las compras se han multiplicado por dos en sólo cuatro años coincidiendo con la caída económica del país controlado por Nicolás Maduro. El incremento de compras inmobiliarias por parte de este colectivo casi triplica al aumento del índice general de adquisiciones de inmuebles por extranjeros, que en 2018 fue del $7 \%$. La mayor parte de las operaciones se cerraron en la Comunidad de Madrid, donde se produjo una de cada tres compras y los venezolanos se sitúan ya entre las principales nacionalidades por compras entre extranjeros. (El Mundo, 19.04.2019)

[In 2018, Venezuelan citizens bought a total of 278 houses in this country, $20 \%$ more than a year earlier and more than twice as much the transactions made in 2014. In other words, purchases have doubled in just four years to coincide with the economic downturn in the country controlled by Nicolás Maduro. The increase in property purchases by this group is almost three times the increase in the general index of property purchases by foreigners, which in 2018 was $7 \%$. The majority of transactions were closed in the Madrid region, where one out of every three purchases took place and 
Venezuelans are now among the leading nationalities in terms of purchases by foreigners. (My translation, S. I.-D.)]

(8) Otros muchos han comprado pisos de más de dos millones de euros en el barrio de Salamanca. En una de sus elegantes calles, Kika Payares y otras tres socias han abierto InCasa, una tienda de decoración orientada al gusto vanguardista de los venezolanos adinerados del barrio. (...). Pero ahora están introduciendo objetos más clásicos porque quieren crecer y han notado cómo el flujo de venezolanos está remitiendo. Buscan atraer al cliente español, más conservador. "El [venezolano rico] que quería salir ya lo hizo", dice Payares. (El País, 08.01.2020)

[Many others have bought flats worth more than two million euros in the Salamanca district. In one of its elegant streets, Kika Payares and three other partners have opened InCasa, a decoration shop oriented towards the avantgarde taste of the wealthy Venezuelans of the neighbourhood. (...). But now they are introducing more classic objects because they want to grow and have noticed how the flow of Venezuelans is receding. They are looking to attract the more conservative Spanish clientele. "The [rich Venezuelan] who wanted to get out already did so”, says Payares. (My translation, S. I.-D.)]

The Venezuelan community in Spain is the migrant group that is recently growing fastest, especially in the capital. For this reason, the district Salamanca in Madrid is also jokingly called pequeña Venezuela 'little Venezuela' or pequeña Caracas 'little Caracas'. Both newspapers refer to the Venezuelan diaspora in Madrid and seem to have a strong focus on hard news since they argue with figures and statistics. Both stress the high socio-economic level of Venezuelan migrants.

The previously discussed examples show a multi-faceted positive representation of Venezuelan migrants. To explain these positive attitudes, the newspapers themselves offer explanations:

(9) Muchos de los 90.220 inmigrantes venezolanos en la región de Madrid tienen pasaporte español porque llegaron con él a Barajas gracias a que son los hijos de los españoles que durante el franquismo se exiliaron o emigraron. De ellos casi 49.500 tienen derecho a voto el domingo por tener pasaporte español. (El País, 15.03.2019)

[Many of the 90,220 Venezuelan immigrants in the Madrid region have a Spanish passport because they arrived in Barajas with it as they are the children of Spaniards who went into exile or emigrated during the Franco regime. Almost 49,500 of them have the right to vote on Sunday because they have a Spanish passport. (My translation, S. I.-D.)]

Example (9) provides a comprehensive explanation of the positive attitudes towards Venezuelan migrants in Spanish press highlighting the close relations between Spain and Venezuela and their common history. 
Venezuelan immigration in Spain is widely associated with the recognition of citizenship; with the Ley de la memoria bistórica 'Historical Memory Law', regulations came into force that facilitated the process of recognising Spanish nationality for the descendants of former Spanish migrants in Latin America (see Freitez 2011: 22).

(10) "Nada detiene la constante huida de españoles a otras tierras: ni las duras condiciones de trabajo, ni los terribles desengaños de millares de desgraciados. La injusticia y la miseria que aquí padecen aterran más que todas las negruras que fuera les aguardan”. La España de 1914 que se perfila en este texto de El Correo de Madrid no es la España de hoy, pero la historia es conocida. (...) Igual que hoy, miles de personas se vieron forzadas a abandonar el país y probar suerte en otros lugares. La mayoría viajaron a México, Argentina, Venezuela, Cuba o algún otro territorio de las antiguas colonias españolas en América. (El Mundo, 30.03.2015)

["Nothing stops the constant flight of Spaniards to other countries: neither the hard working conditions nor the terrible disappointments of thousands of unfortunates. The injustice and misery they suffer here is more terrifying than all the blackness that awaits them outside". The Spain of 1914 that is outlined in this text from El Correo de Madrid is not the Spain of today, but the history is well known. (...) Just as today, thousands of people were forced to leave the country and try their luck elsewhere. Most travelled to Mexico, Argentina, Venezuela, Cuba, or some other territory of the former Spanish colonies in America. (My translation, S. I.-D.)]

El Mundo recalls the reverse migratory flow of Spaniards to Venezuela and other Latin American countries, which has a high degree of relevance to Spain both over a hundred years ago and in the present. In this way, the positive image of Venezuelans is explained through the remembrance of their common history.

\section{Discussion and outlook}

The overall results can be summarised as follows: First of all, the coverage of Venezuelan migrants in El Pais is higher than in El Mundo. Secondly, important insights arose from the collocation analysis. There is a high degree of common collocates for venezolano, $-a$ in $E l$ Pais and El Mundo. This relative homogeneity of the coverage in Spanish press is an astonishing result. Hence, the first hypothesis of differences in the reporting between El Pais and El Mundo is rejected. Thirdly, the qualitative analysis revealed that both broadsheets attribute positive values to Venezuelan migrants. They are represented as well educated, an economic and cultural asset to Spain and their elite 
is mentioned. Furthermore, both dailies tell success stories of Venezuelan migrants. Therefore, the second hypothesis of a negative representation of Venezuelan migrants in Spanish press cannot be corroborated.

The reason for these findings is shown in the reporting, as close ties between Spaniards and Venezuelans are brought into focus. From a theoretical perspective, the results can be explained using the theory of the so-called othering:

The manifold discursive forms of inclusion and exclusion define who are considered "Europeans" and create an "imagined community" that necessarily excludes "others". Hegemonic discursive forms of inclusion and exclusion create an "imagined community" that does not comprise "others". Those who are not worthy of becoming Europeans (...) and who are usually represented as "strangers" or even "enemies". Border and identity converge to keep specific strangers out while letting others in. (Wodak 2007: 651)

A second explanatory approach is based on the presentation of the high socio-economic level of Venezuelans and their property purchases. This relates to the concept of the so-called aporofobia introduced by the Spanish philosopher Adela Cortina (2017). The name already reveals the

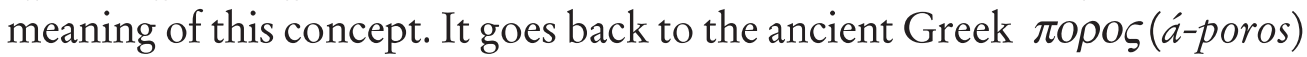
which means 'indigent, poor' and $\phi \beta o \varsigma$ (phobos) 'fear'. It thus expresses hostility towards destitute people who have no resources. Such a feeling and attitude are acquired. What is surprising about the results is that in the case of reporting on Venezuelan migrants, the concepts of othering and aporofobia can be used to explain not exclusion but inclusion.

The attitudes of the host community are relevant for the integration process of a migrant group (cf. chapter 1). Therefore, from a theoretical point of view, this article has forged new paths in the study of language and migration by focusing on the perspective of Spanish media towards Venezuelan migrants. It makes an important contribution in this field to demonstrate that migrants are not always discursively constructed as "bad" migrants in the media. In this context, it is crucial to investigate the reasons for discursive constructions of "good" and "bad" migrants - and the (historical) variability of these ascriptions. Press coverage does not simply depict facts and reflect the "truth". Rather, reporting contributes to a discursively constructed reality by revealing attitudes and by interpreting events and developments in opinion-laden articles. Media assume broad responsibility as they are both, mediators between different actors - such as politicians and society - and co-creators of a discursive constructed social reality (see Böhm 2015: 267). 
Sandra Issel-Dombert

Ruhr-Universität Bochum

Romanisches Seminar

Universitätsstraße 150

44780 Bochum

sandra.issel-dombert@rub.de

ORCID: https://orcid.org/0000-0003-2538-1789

Recepción: 13/01/2021; Aceptación: 12/06/2021

\section{Notas}

1 I Official data on Venezuelans migrants is impossible to come by

2 See https://www.tagesschau.de/ausland/venezuela-fluechtlingskrise-101.html (02.10.2020).

3 Negative representations of migrants and refugees are not an isolated case. For example, they have been proven several times in British press discourse (see Rheindorf/Wodak (2020)).

${ }^{4}$ See https://www.prisa.com/en/noticias/noticias-1/el-pais-the-worlds-most-widelyread-digital-newspaper-in-spanish- (13.10.2020).

5 https://www.sketchengine.eu/my_keywords/collocation/ (23.10.2020).

6 "The word sketch processes the word's collocates and other words in its surroundings. It can be used as a one-page summary of the word's grammatical and collocational behaviour. The results are organized into categories, called grammatical relations.", see https://www.sketchengine.eu/guide/word-sketch-collocations-and-word-combinations/ (23.10.2020).

7 https://www.sketchengine.eu/my_keywords/logdice/ (23.10.2020).

8 Plötner (2018: 164) also points out that in terms of content no clear differences between the two newspapers can be established.

9 https://dle.rae.es/exiliado (23.10.2020).

\section{References}

Böhm, Véronica. 2015. "Immigrationspolitische Diskurse in Spanien: Re-aktiver und Proaktiver Diskurs. Eine Frame-Diskursanalyse.” En Politische und mediale Diskurse. Fallstudien aus der Romania, Anja Hennemann y Claudia Schlaak (eds.), 243-269. Berlin: Frank \& Timme.

Baker, Paul, Costas Gabrielatos, Majid Khosravnik, Michal Kryzanowski, Tony McEnery, and Ruth Wodak. 2008. "A useful methodological synergy? Combining critical discourse analysis and corpus linguistics to examine discourses of refugees and asylum seekers in the UK press". Discourse and Society, 19:3. 273-306.

Cortina, Adela. 2017. Aporofobia, el rechazo al pobre: Un desafío para la democracia. Barcelona: Ediciones Paidós.

CIS. 2020. "Principales problemas para los españoles", in: https://www.epdata.es/datos/ principales-problemas-espanoles-cis/45, [consulted on 22/10/2020].

De Fina, Anna. 2018. "What is your dream? Fashioning the migrant self". Language E Communication 59. 42-52.

EASO. 2020. "Venezuela Country Focus. Country of Origin Information Report", in: https://coi.easo.europa.eu/administration/easo/PLib/2020_08_EASO_COI_Report_ Venezuela.pdf, [consulted on 04/12/2020]..

Lengua y migración / Language and Migration 13:2 (2021), 7-28

Edición impresa: ISSN 1889-5425. Edición en línea: ISSN 2660-7166. @ ( Universidad de Alcalá 
El País. 2016. EL PAÍS, the world's most widely read digital newspaper in Spanish. https://www.prisa.com/en/noticias/noticias-1/el-pais-the-worlds-most-widely-readdigital-newspaper-in-spanish-, [consulted on 13/10/2020].

Encovi. 2017. "Encovi 2017”, https://www.proyectoencovi.com/encovi-2017, [consulted on 01/10/2020].

Encovi. 2019-2020. "Encuesta Nacional de Condiciones de Vida”, https://www.proyectoencovi.com/informe-interactivo-2019, [consulted on 13.10.2020].

Evert, Stefan. 2008. "Corpora and collocations". En Corpus linguistics: An international handbook, Anke Lüdeling y Merja Kytö (eds.), 1212-1248. Berlin: Mouton de Gruyter.

Evolución de las concesiones de nacionalidad española por residencia según sexo y provincia del Registro Civil. 2006-2015. http://extranjeros.mitramiss.gob.es/es/ estadisticas/operaciones/concesiones/index.html, [consulted on 02/10/2020].

Freitez L., Anitza. 2011. "La emigración desde Venezuela durante la última década". Temas de Coyuntura 63. 11-38.

Franquet Santos Silva, Miguel, Real Rodríguez, Elena y Beriain, Ana. 2015. "La representación mediática de la inmigración en cuatro diarios españoles”. Opción, 31:1. 283303.

Feline Freier, Luisa y Castillo Jara, Soledad. 2020. “Die Krise um die Migration aus Venezuela”, Online publication: https://www.bpb.de/gesellschaft/migration/ laenderprofile/304728/venezuela\#footnode10-9, [consulted on 27/08/2020].

Froehlich, Laura and Schulte, Isabel. 2019. "Warmth and competence stereotypes about immigrant groups in Germany”. PloS One, 14:9. 1-17.

Garrido, M. Rosa y Codó, Eva. 2017. "Deskilling and delanguaging African migrants in Barcelona: Pathways of labor market incorporation and the value of global English." En Skilled Migration and Global English. Special issue of Globalisation, Societies and Education, Frances Giampapa y Suresh Canagarajah (eds.), 29-49. Abingdon: Routledge.

Giró, Xavier y Jarque, José Manuel. 2006. “Prensa escrita e inmigración. Estudio sobre la opinión de los diarios sobre la inmigración procedente de fuera de la Unión Europea y sobre la cobertura informativa de conflictos destacados que tienen relación con ella (Octubre 1999-Junio 2002)." Zer. Revista de estudios de comunicación, 20. 251-270.

Gruber, Teresa. 2018. "Metaphorische Konzeptualisierungen der ,Flüchtlingskrise" in der spanischen, italienischen und deutschen Medienberichterstattung”. En KRISE. Mediale, sprachliche und literarische Horizonte eines viel zitierten Begriffs, Marie Schoeß y Marko Zejnelovic y Laura Kohlrausch (eds.), 59-85. Würzburg: Königshausen \& Neumann.

Igartua Perosanz, Juan José, José Antonio Otero y Carlos Muñiz. 2007. “El tratamiento de la inmigración en los medios de comunicación un análisis comparativo entre prensa y televisión." En Medios de comunicación, inmigración y sociedad, Juan José Igartua Petrosanz y Carlos Muñiz (eds.): 149-172. Salamanca: Ediciones Universidad de Salamanca.

INE. 2020. Población extranjera por Nacionalidad, provincias, Sexo y Año. https://www.ine.es/jaxi/Datos.htm?path=/t20/e245/p08/10/\&file=02005.px\#! tabstabla, [consulted on 02/10/2020].

International Organization for Migration, IOM. 2020. Venezuelan Refugee and Migrant Crisis. https://www.iom.int/venezuela-refugee-and-migrant-crisis (30.09.2020).

Issel-Dombert, Sandra/Wieders-Lohéac, Aline. 2018. “Auf Flüchtlingswellen surft man nicht vor Lampedusa - Zur Metaphorik des öffentlichen Diskurses zur Flüchtlingskrise Italiens”. Metaphorik.de, 28:1. 77-97.

Issel-Dombert, Sandra. 2019. "Vivir entre dos mundos - Mehrsprachigkeit, Identität, Sprach- und Kulturkontakt”. Romanistik in Geschichte und Gegenwart, 25:1. 31-57.

LexisNexis. 2020. Lexis Nexis. https://www.lexisnexis.de/?gclid=CjOKCQjw8fr7BRD SARIsAK0Qqr5ztczRVoFQsy18o9idZKdmPUQ855F7gQO3E_-0YdxAtLqJ C1TBxzkaAgfqEALw_wcB, [consulted on 10/10/2020]. 
Páez, Tomas y Phélan, Mauricio. 2019. "Emigración venezolana hacia España en tiempos de revolución bolivariana (1998-2017)". Revista Internacional de Estudios Migratorios, 8:2. 319-355.

Plötner, Kathleen. 2018. "Frenar los flujos - Zur Funktion und Wirkweise von Metaphern des spanischen Flüchtlingsdiskurses". Metaphorik.de, 28:1. 133-168.

Real Academia Española. 2014. Diccionario de la lengua española. On line. https://dle.rae.es/exiliado, [consulted on 23/10/2020].

Rheindorf, Markus y Wodak, Ruth. 2020. "Building 'Fortress Europe': Legitimizing Exclusion from Basic Human Rights." En Sociolinguistic Perspectives on Migration Control. Language Policy, Identity and Belonging, Markus Rheindorf y Ruth Wodak (eds.), 116-147. Bristol/Blue Ridge Summit: Multilingual Matters.

Salas Guerra, Luis. 2011. "El discurso periodístico sobre la inmigración latinoamericana en España: el corpus de IMMIGRA". Lengua y migración, 3:1. 33-51.

Sancho Pascual, María. 2019. "Integrating the immigrant population into the city of Madrid (Spain): preliminary data about the sociolinguistic attitudes of the host community". Journal of multilingual and multicultural development, 41:1. 1-13.

Scheufele, Bertram and Hans-Bernd Brosius. 2001. "Gewalt durch „Fremde“ - Gewalt gegen „Fremde“. Die Berichterstattung über PKK und Kurden-Gewalt und fremdenfeindliche Straftaten". Politische Vierteljabresschrift, 42:3. 447-473.

Sketch Engine. 2020a. Collocation. https://www.sketchengine.eu/my_keywords/collocation/ (23.10.2020)

Sketch Engine. 2020b. Sketch engine. https://www.sketchengine.eu, [consulted on 23/10/2020].

Varga Ribas, Claudia. 2018. "La migración en Venezuela como dimensión de la crisis". Pensamiento proprio, 47. 91-128.

OECD/EU. 2018. "Settling In 2018: Indicators of Immigrant Integration. Paris/Brüssel: OECD Publishing”. URL: https://read.oecd-ilibrary.org/social-issues-migrationhealth/indicators-of-immigrant-integration-2018_9789264307216-en\#page70, DOI:https://doi.org/10.1787/9789264307216-en, [consulted on 03/05/2020].

Tagesschau. 2020. https://www.tagesschau.de/ausland/venezuela-fluechtlingskrise-101.html, [consulted on 02/10/2020].

UNHCR. 2020. "Venezuela situation", https://www.unhcr.org/venezuela-emergency.html, [consulted on 03/09/2020].

von Tschilschke, Christian. 2013. "Die Medienlandschaft in Spanien". En Handbuch Spanisch. Sprache, Literatur, Kultur, Geschichte in Spanien und Hispanoamerika, Joachim Born y Robert Folger y Christopher F. Laferl y Bernhard Pöll (eds.), 635639. Berlin: ESV.

Wodak, Ruth. 2007. "Discourses in European Union organizations: Aspects of access, participation, and exclusion". Text and Talk, 27:5-6. 655-680.

Zapata-Barrero, Ricard and Van Dijk, Teun A. 2007. "Introducción: inmigración y discurso". En Discourses on Immigration in Spain: The Media, Parliaments and Administration, Ricard Zapata-Barrero y Teun A. Van Dijk (eds.): 9-14. Barcelona: Edicions Bellaterra.

Zimmermann, Klaus y Morgenthaler García, Laura (2007): “Introducción: ¿Lingüística y migración o lingüística de la migración? De la construcción de un objeto científico hacia una nueva disciplina". RILI V, 2:10. 7-19. 